\title{
DE BAUXIETNIJVERHEID EN DE STICHTING VAN EEN NIEUWE STAD IN SURINAME. \\ DOOR
}

FRED. OUDSCHANS DENTZ.

\section{De ontdekking van Bauxiet.}

Ofschoon J. Middelberg, de gewezen leider der Mijnexploratie van Gouvernementswege in Suriname, in 1907 schreef ${ }^{1}$ ) „dat er voorshands geen redenen bestaan om „aan te nemen, dat andere delfstoffen dan goud in ont„ginbare hoeveelheden in Suriname worden aangetrof„fen” en verder ${ }^{2}$ ) „van eenig belang voor den werkelijken „mijnbouw is echter alleen het goud en het is te ver"wachten dat slechts de ontginning van dit metaal, voor „de mijnindustrie van Suriname van belang zal zijn," heeft de aanwezigheid in groote ontginbare hoeveelheden van Bauxiet en ijzererts, die uitspraak te niet gedaan.

Het mag wel opmerkelijk worden genoemd dat in Britsch-Guyana en in Suriname ongeveer gelijktijdig bauxietlagen werden gevonden.

In 1897 ontdekte Professor J. B. Harrison, C. M. G. Director of Agriculture and Science, dit erts in BritschGuyana in een heuvel te Akyma aan de Demerararivier ${ }^{3}$ ) waarvan geanaliseerde monsters zeer gunstig werden beoordeeld. Zijn verslag werd opgenomen in „The Official Gazette" van 16 Juli 1910. Hierin wordt onder meer gezegd: „At present probably these deposits are of too low

1) Geologische en technische aanteekeningen over de goudindustrie in Suriname door E. Middelberg, Amsterdam 1908, blz. 5.

$\left.{ }^{2}\right)$ Alsvoren blz. 7 .

3) Report of the condition of the colony of British Guiana during the great European war and of the chief local problems awaiting solution, by C. Clementi, Officer administering the Colony, 1919. 
„commercial value to warrant their exploitation for ex„port as sources of aluminium, but their exceptional puri„ty renders it desirable for their occurrence to be placed "on record."

"In the future they may be of use as sources of alu„munium or of alumina and its salts, whilst the calcined ,product by its infusibility may prove of use for furnace"linings etc."

De mijningenieur Dubois, die in dienst der voormalige maatschappij Suriname van 1898/1900 in de kolonie geologische onderzoekingen deed, maakte in zijn werk: „Beitrag zur Kenntnis der Surinamischen Laterit und Schutzrindenbildungen" op blz. 34 melding van het voorkomen van dit erts en voegt daarbij: „Man trifft es nicht selten aber bis jetzt in noch nicht abbauwürdiger Kwantität an".

Alhoewel het bestaan van Bauxiet dus reeds een 23-tal jaren geleden bekend was in de West-Indische Koloniën, is eerst sedert den grooten Europeeschen oorlog de aandacht meer op dit metaal gevestigd omdat de behoefte aan de grondstof voorheen gering was en de marktprijs laag. Hierin kwam een groote en gunstige verandering sedert 1914 en werden een 6-tal jaren geleden in Engelsch zoowel als in Nederlandsch Guyana ernstige pogingen aangewend om dit voor de toekomst belangrijke erts te doen ontginnen.

De stoot daartoe gaf Britsch-Guyana en Suriname volgde. De eerste persoon die hier onder den naam van Thomson in 1914 op dit doel afkwam van uit Amerika, was de heer Morest, die monsters bauxiet in de stad medebracht uit het binnenland. De heer Harvey kan als een der pioniers worden beschouwd en verschillende andere onderzoekers als Pay en Headley droegen het hunne bij om meer en meer de aandacht op dit erts te vestigen en kapitaal voor de ontginning te vinden. Een groot aantal aanvragen om vergunning tot het doen van onderzoek naar de aanwezigheid van delfstoffen, klaarblijkelijk met het oog op bauxiet-onderzoek, werden ingediend en een niet minder groot aantal van die conces- 
siën werd overgenomen door eene Amerikaansche maatschappij, welker onderzoekingen ter plaatse gunstige uitkomst hadden. De op 19 December 1916 opgerichte Naamlooze Vennootschap „De Surinaamsche BauxietMaatschappij" verkreeg concessie op een uitgestrektheid van $123.053 \mathrm{H}$.A. en eigendom door aankoop van particulier bezit van \pm 5000 H.A. Ook een andere Amerikaansche Maatschappij: „De Norton Compagnie”, werkte voor datzelfde doel. Bepalen wij ons echter tot de eerstgenoemde maatschappij, een afdeeling van de „Republic Mining and Manufe cturing Comp." te Philadelphia, een afdeeling wederom van de groote „Aluminium Company of America" die haar werkzaamheid is aangevangen en over welker arbeid ik een en ander wil schetsen.

\section{Wettelijke bepalingen, regelende het Bauxiet-bedrijf.}

Bij de opening van het 52e zittingjaar der Koloniale Staten deed de Gouverneur eene toezegging ${ }^{1}$ ) om wettelijke regelen te treffen en bood hij bij brieven van 19 Januari no. 236 en 237 aan het genoemd college aan een verordening houdende bepalingen omtrent het doen van onderzoek naar de aanwezigheid en omtrent het ontginnen van bauxiet in of op den bodem van Suriname ${ }^{2}$ ) en op bauxietbelasting ${ }^{3}$ ). Het voorloopig verslag van de Koloniale Staten verscheen 26 Februari d.a.v., de Memorie van Antwoord op 12 Maart. Hierop volgde een nota van wijzigingen. Op 16 Maart brachten de Koloniale Staten hun eindverslag uit. Het lid van Ommeren diende 22 Maart zes amendementen in. Gelijke data dragen de gewisselde stukken ten aanzien van de Bauxietbelasting. Deze beide verordeningen - de Bauxietverordening en de Bauxietbelasting - werden in de vergadering van 26 Maart behandeld ${ }^{4}$ ) en goedgekeurd en gepubliceerd in

\footnotetext{
1) Punt 19 v. d. openingsrede uitgesproken door Gouverneur Staal op Dinsdag 8 Mei 1917.

$\left.{ }^{2}\right)$ Handelingen der Kol. Staten. Bijlagen 1917-1918 (21-1/8).

3) Handelingen der Kol. Staten. Bijlagen 1917-1918 (22-1/6).

4) Handelingen der Kol. Staten. vol. 40-44, Blz. 133-149.
} 
het Gouv. Adv. Blad no. 76 van 1918. Binnen 9 weken was dus alles afgeloopen.

Als men nu nagaat dat de vereischte goedkeuring van Nederland zoolang uitbleef, dat, na de mededeeling ${ }^{\mathbf{1}}$ ) van den ondervoorzitter van den Raad van Bestuur dat telegrafisch bericht was ontvangen dat de Bauxietverordening kon worden afgekondigd, doch gelijkertijd aan de Staten eene wijzigingsverordening zou moeten worden aangeboden, eerst op 24 November 1919 eene wijziging in de bauxietverordening werd gepubliceerd, welke het opperbestuur in het moederland noodzakelijk achtte ${ }^{2}$ ) alvorens de Koninklijke goedkeuring aan de verordening kon worden gehecht, welke wijzigingen de Koloniale Staten na indiening ${ }^{3}$ ) onmiddellijk afdeden ${ }^{4}$ ), en bij Resolutie van 28 Nov. 1919 no. 2885, bepaald werd dat de drie verordeningen - bauxietverordening, bauxietbelasting en wijziging bauxietverordening - op 1 Januari 1920 in werking zouden treden, dan kan hieruit wel worden verklaard dat een dergelijke vertraging in de afdoening buiten de kolonie, terecht of ten onrechte veel ontstemming heeft veroorzaakt in Suriname, omdat de Sur. Baux. Mij. hare eenmaal aangevangen werkzaamheden niet krachtig kon voortzetten, voordat er wettelijke zekerheid zou bestaan voor het bedrijf, waarvoor de Mij. zich reeds aanzienlijke offers getroost had. Immers in de 4 jaren - het onderzoek inbegrepen - dat de Sur. Baux. Mij. in de kolonie werkzaam was, had zij met inbegrip der koopsommen, reeds een groot kapitaal uitgegeven.

Bij Resolutie van 8 November 1919 no. 3886 (G. B.

1) Vergadering der Kol. Staten van 6 Mei 1918, waarin behandeld werd de Kol. Huish. Begrooting van Suriname voor het dienstjaar 1920. - Handelingen der Kol. Staten 1917-1918, vol. 64. blz. 233.

$\left.{ }^{2}\right)$ Deze wijzigingen strekken in hoofdzaak om de betalingen en heffingen te verhoogen en den arbeidsdrang te versterken. Hiertoe was door den Min. v. Koloniën, overleg gepleegd met den vice-voorzitter van de Aliminium Company, den heer Darling, die zich daarvoor naar Nederland had begeven.

$\left.{ }^{3}\right)$ Ingediend bij brief van den Gouverneur van 19 November 1919 No. 3799.

4) Zitting van 24 November 1919. Handelingen der Koloniale Staten $1919 / 1920$, vol. 15 , blz. $53 / 54$. 
no. 80) werd de geldende tekst van de Bauxietverordening 1919 (G. B. no. 76) gepubliceerd en werden, ter uitvoering van sub 6 van art. 10 daarvan, bij Besluit van 30 Dec. 1919, de noodige voorschriften gegeven omtrent het toezicht op de naleving van de bepalingen (G. B, 1919 no. 84).

Ten slotte bood de Gouverneur op 20 April 1920 aan de Koloniale staten eene verordening aan tot nadere wijziging van de Bauxietverordening 1919, welke bepaalt dat geschillen nopens het voldoen aan de vereischten door houders van vergunningen tot onderzoek naar de aanwezigheid en van de concessiën tot het ontginnen van bauxiet, beslist worden door den rechter en op de wijze, als geregeld is in de verordening van April 1903 (G. B. no. 17). Deze verordening werd door de Kol. staten goedgekeurd in haar zitting van 23 Juni 1920 en is nog niet ${ }^{\mathbf{1}}$ ) afgekondigd.

\section{Moengo. (Mongo.)}

Het mag welhaast op een sprookje gelijken, dat in het verafgelegen, in Nederland vrij wel onbekende Suriname, waar de toestand in de laatste jaren verre van rooskleurig was, een nieuw dorp uit den grond verrezen is, dat in bevolkingsaantal thans Albina ter zijde streeft, een dorp, midden in de wildernis, hoogop de rivier de Boven-Cottica, ver van de bewoonde wereld en de beschaving van het overige deel der kolonie.

De stichting van dit dorp Moengo is een roman, een stuk moderne geschiedenis en een monument voor de wilskracht en de volharding der Amerikanen. Wij zijn tot nu toe gewend geweest alleen te lezen van het ontstaan van dorpen en steden in Noord-Amerika, vooral daar, waar na het vinden van goud en diamanten, stroomen landverhuizers zich hebben begeven. Hier evenwel, een stelselmatig aanleggen en opbouwen van de vierde plaats der kolonie, langzamerhand groeiend in bevolkingsaantal en oppervlakte in normale verhouding.

$\left.{ }^{1}\right)$ Bijlagen 1919-1920 (41.1./3); 1920-1921 (1.1). 
Honderd en vier mijlen van Paramaribo aan de BovenCottica tusschen de Suriname en Marowijnerivieren, ligt het dorp Moengo of Mongo, een vroeger Aucaner Boschnegerdorp, dat sedert lang verlaten was, naar men meent, omdat de harde grond het inslaan van palen voor de woningen zoo moeilijk maakte.

Moengo beteekent heuvel. De Djoeka's noemen het „Oeman Kondre" (vrouwenland) in tegenstelling met Paramaribo, dat ze "Soeman Kondre” (menschenland) noemen. Moengo is golvend terrein, de bauxietlagen, die dicht aan de oppervlakte liggen en doorloopen tot den rivieroever, worden aangetroffen over een lengte van 5 K.M., een breedte van $300-500 \mathrm{M}$. en een dikte tot $4 \mathrm{M}$. Het emplacement Moengo, dat nu het dorp Moengo genoemd mag worden, de S. B. M. noemt het een stad, is \pm 3200 H.A. groot. De heuvel Moengo is ongeveer 45 voet hoog en strekt zich eenige K.M. langs de Cottica uit en landwaarts tot een diepte van ongeveer $800 \mathrm{M}$.

Het concessieterrein van de S. B. C. bevat talrijke heuvels. Ik telde op de kaart $23^{1}$ ) waarvan de Moengoheuvel de belangrijkste is. De aanleg van het dorp is berekend op ongeveer 1000 arbeiders, met vrouwen en kinderen, eene bevolking uitmakendë van een 4000 personen. Het bouwplan volgens nevenstaande schets is in 1919 geteekend. De laatste aanvulling daarvan had 10 April 1920 plaats. Het dorp wordt verdeeld in drie wijken, bestemd voor: $1^{\circ}$. de Amerikanen (C), $2^{\circ}$. de Surinaamsche of Creolen arbeiders (A), $3^{\circ}$. de Javaansche arbeiders (B).

De stad is in straten van $15 \mathrm{M}$. breedte verdeeld, wier namen op 24 November 1919 gegeven werden.

Men is hierbij zoodanig te werk gegaan, dat de loodrecht op de rivier uitkomende straten zijn genoemd van 1 tot en met 10 en de deze kruisende straten de namen hebben ontvangen van Surinaamsche houtsoorten.

1) Te weten: Moengo Hill, New Boon Hill, Mana Hill, Buschman Hill, Naman Hill, 3 Ajoemakondre Hills, 6 Lobato Hills, 2 Sunday Hills, Red Hill, Last Hill, Lost Hill, 2 Jones Hills en 2 Wana Hills, waarvan de cursief gedrukte zijn genoemd naar oorspronkelijke concessionarissen en den Amerik. ingenieur Naman. 


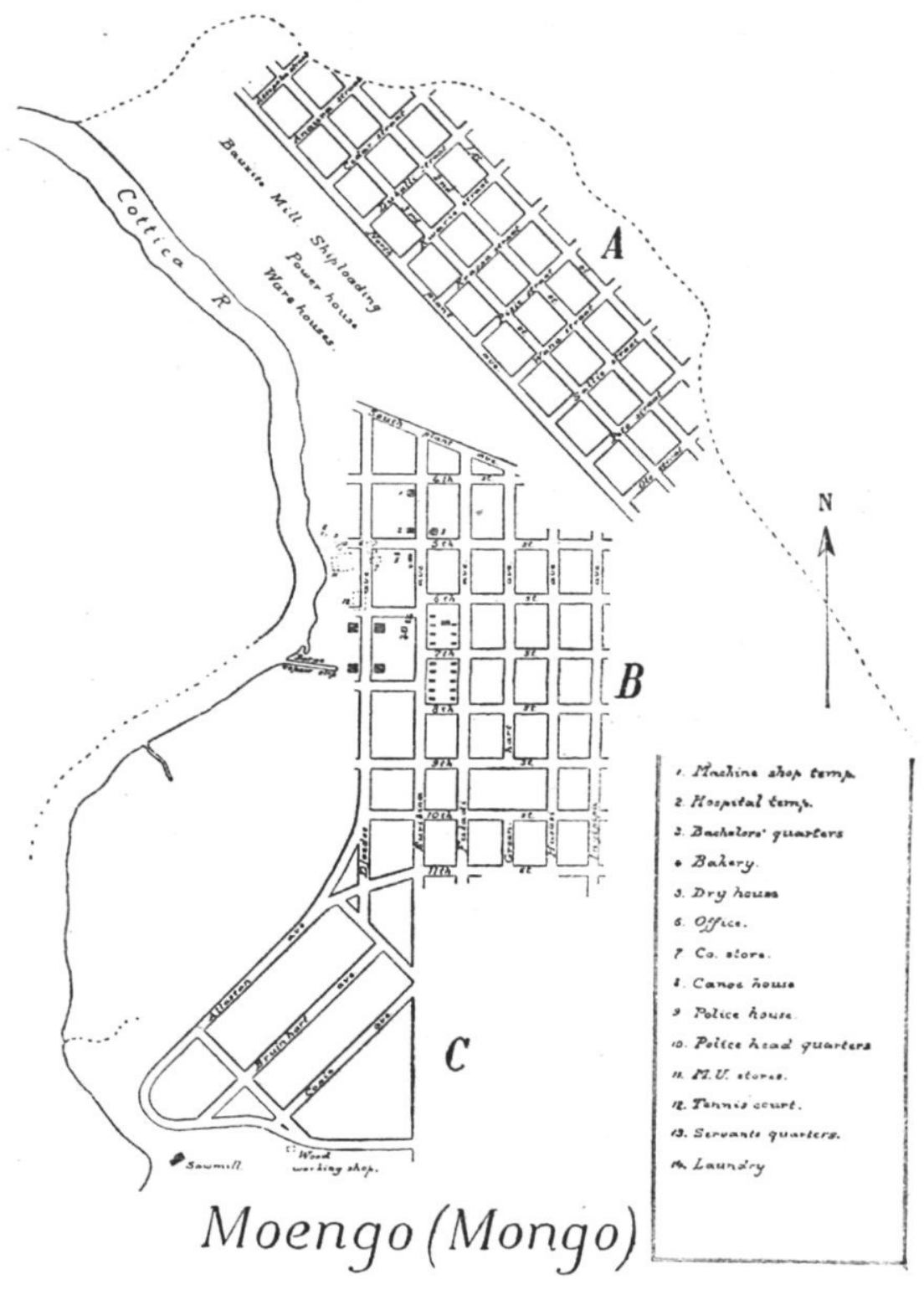

1. Platte grond van Moengo. 
In de Surinaamsche wijk noemt men ze „straten” en den hoofdweg "North plant avenue”, in het middengedeelte en in de Amerikaansche wijk ,avenues”. Evenals de moderne steden in Amerika loopen de straten loodrecht op elkaar en vormen in de Surinaamsche en in de middenwijken ieder 50 blokken en in de Amerikaansche wijk 4 blokken. De straten loopen alphabetisch van de rivier op naar boven.

De blokken van de Surinaamsche en Javaansche arbeiderswijken hebben een afmeting van 60 bij 75 M., die van de Amerikaansche wijk zijn belangrijk grooter.

Achtereenvolgens zullen we behandelen: A. de hygiëne B. de bedrijven, C. de administratie, D. de organisatie, E. de sociale arbeid, F. de overheidstaak, G. de toekomst.

\section{A. D e H y g i ën e.}

Waar de zin voor hygiëne bij de Amerikanen sterk ontwikkeld is en de door deze natie op dit gebied verrichte arbeid in Panama, Cuba, Haïti een voorbeeld is voor de overige wereld, daar behoeft het geen verwondering te baren, dat deze beginselen een toepassing zulllen vinden in Suriname dat in de benijdenswaardige positie verkeert dat aldaar een stad in aanbouw is, welke aangeleg wordt volgens de moderne beginselen der hygiëne en wel die voor de tropen.

Het ontbosschen van het terrein waarop Moengo is gelegen, is al een groot stuk werk geweest. Deze ontbossching gaat geregeld voort. De zwampige terreinen groot \pm 400 acres in de omgeving van Moengo zullen in de toekomst ingepolderd worden. Er wordt geld noch moeite gespaard om van Moengo een plaats te maken waarop Suriname trotsch kan zijn en waar de tropische ziekten, met name Malaria, Anchylostomiasis enz. geen kweekplaatsen zullen vinden.

Om te beginnen heeft de maatschappij zich verzekerd van een Nederlandsch geneesheer-bacterioloog, den heer C. Bonne, tot voor zijn indiensttreding, officier van Gezondheid 2e kl. bij het N.-I. leger, die jaren in het 